Reprod. Nutr. Dévelop., 1980, 20 (3 A), 631-636.

\title{
Effect of diet and ovariectomy on adipose tissue cellularity in mice
}

\author{
par E. PALLIER *, Roberte AUBERT, D. LEMONNIER \\ Unité de Recherches sur lo Nutrition ef l'Alimentation, U1 de I'INSERM, \\ Hôpital Bichat, 170, bd Ney, 75018 Paris, France.
}

Summary. Three-week old female mice were ovariectomized. From weaning at 4 weeks they were fed either a control or a high fat diet. When 32 weeks old, the ovariectomized mice weighed more than the sham-operated ones, whichever diet they were fed. Food intake decreased 140 days after castration. Ovariectomized mice fed the control diet showed fat cell hypertrophy at three sites and hyperplasia of the perirenal tissue. In mice fed the fat-rich diet, ovariectomy only caused further hypertrophy in the subcutaneous and perirenal adipose tissue.

\section{Introduction.}

Ovarian hormones play a role in the body weight regulation of female rats (Wade, 1975). During proestrus, food intake and body weight decrease (Brobeck ef al., 1947), while ovariectomy results in an increase of these factors (Kakolewski et al., 1968). When high chronic doses of estrogens are given, the growth hormone level elevates, leading to the depletion of fat stores and a reduction of fat cell size (Batchelor and Mahler, 1972). These hormones, therefore, seem likely candidates for modifiers of adipose cellularity in different fat tissue regions. On the other hand, obese female mice frequently show fat cell hyperplasia and/or hypertrophy according to the site (as observed in obesity induced by a high fat diet), and cell size and number increase dramatically at the genital site ; no increment has been found at that site in males (Lemonnier, 1972). The aim of this study was to defermine the effect of ovariectomy on the adipose cellularity of female mice fed a control diet or one known to increase fat cell size and number.

\section{Material and methods.}

Swiss female mice (Lessieux, Sèvres) born in the laboratory from litters of 4 to 11 pups, and then raised in litters of 9 pups each (Aubert ef al., 1971), were weaned at

* Present address : Groupe de Recherches de Nutrition et Diététique, U59 de l'INSERM, 40, rue Lionnois, 54000 Nancy, France. 
4 weeks. From then on, one group was fed a high fat diet with lard (diet $L: 72$ p. 100 fat in calories), while the other was given a control diet ( 9 p. 100 fat in calories) (Lemonnier, 1972). Water and food were provided ad libitum to all mice. The animals were housed 5 to a polypropylene cage in a room with 12 hrs of light per day and a temperature of $22 \circ \pm 1$. Body weight was recorded weekly.

Ovariectomy was performed under ether anesthesia at 3 weeks through a double ventrodorsal incision. Sham ovariectomy was identical, except that the uterine horns were not ligated or the ovaries excised. At 22 to 24 weeks, the mice were housed individually 15 days before we measured food intake over a 10-day period.

At 32 weeks, the mice were killed by decapitation. We noted the weight of the sartorius muscle and the three fat pads (parametrial, perirenal and abdominal subcutaneous adipose tissue) and the length of the femur. Total fat cell number and size were measured at those sites as described previously by Lemonnier (1972) : the adipose cells on portions of the histological sections were counted on slides, projected on the ground glass of a microscope at X130 magnification. The mean volume of the cells was calculated from their corrected area on the ground glass, and their number was estimated by the ratio of fat pad weight to mean cell volume $\times 0.91$ ( $0.91=$ estimated pad density). Significance was determined by analysis of variance with a $2 \times 2$ factorial design.

\section{Results.}

Body and organ weights (table 1). - At 32 weeks the ovariectomized mice weighed significantly more than the control sham-operated ones, whichever diet they ate. The difference in body weight between the control and ovariectomized mice could not be due to a difference in growth : tail and femur length and sartorius muscle weight were similar in all groups. Ovariectomized mice fed the control diet showed a significant increase in the weight of the three fat pads. Ovariectomized mice given the high fat

TABLE 1

Body and organ weights of 32-week old ovariectomized (O) or shamoperated (at 3 weeks) female mice fed either a control diet (C) or a high fat diet (L) ad libitum $(M \pm S E M)$

\begin{tabular}{|c|c|c|c|c|c|c|c|c|c|c|}
\hline & $c$ & & & $\mathrm{CO}$ & & L & & & LO & \\
\hline 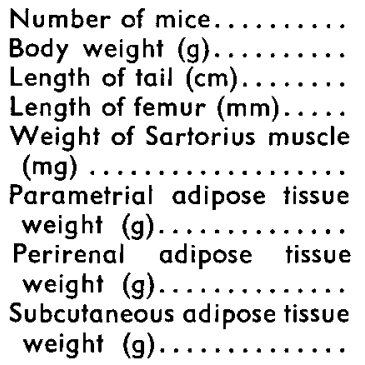 & $\begin{array}{r}36.5 \\
10.0 \\
16.7 \\
124.2 \\
2.0 \\
0.35 \\
0.67\end{array}$ & $\begin{array}{l}13 \\
\pm 0.62 \\
\pm 0.13 \\
\pm 0.17 \\
\pm 3.47 \\
\pm 0.11 \\
5 \pm 0.017 \\
7 \pm 0.038\end{array}$ & $\begin{array}{c}* \\
* * \\
* *\end{array}$ & $\begin{array}{r}43.6 \\
10.5 \\
16.9 \\
126.3 \\
3.2 \\
0.79 \\
1.31\end{array}$ & $\begin{array}{l}10 \\
\pm 2.24 \\
\pm 0.14 \\
\pm 0.26 \\
\pm 4.20 \\
\pm 0.48 \\
\pm 0.122 \\
1 \pm 0.153\end{array}$ & $\begin{array}{r}47.5 \\
9.8 \\
16.9 \\
126.6 \\
6.1 \\
0.98 \\
1.37\end{array}$ & $\begin{array}{l}6 \\
\pm 2.37 \\
\pm 0.21 \\
\pm 0.16 \\
\pm 7.87 \\
\pm 0.83 \\
\pm 0.082 \\
\pm 0.202\end{array}$ & $* *$ & $\begin{array}{r}51.2 \\
10.4 \\
16.8 \\
120.8 \\
6.1 \\
1.34 \\
2.01\end{array}$ & $\begin{array}{l}7 \\
\pm 2.80 \\
\pm 0.07 \\
\pm 0.24 \\
\pm 8.65 \\
\pm 0.88 \\
4 \pm 0.172 \\
1 \pm 0.245\end{array}$ \\
\hline
\end{tabular}

* Significant difference $\mathrm{p}<0.05$ : ** Highly significant difference $\mathrm{p}<0.01$. 
diet had significantly heavier perirenal and abdominal subcutaneous fat pads than the control sham-operated animals.

Food intake (table 2). - Food intake was reduced in the ovariectomized control mice. Ovariectomized mice fed the high fat dief only showed a decrease in food intake when it was expressed per $100 \mathrm{~g}$ of body weight; the food intake in sham-operated mice, when expressed that way, evidenced no divergence whether they ate a high fat or a control diet.

TABLE 2

Food intake of 22 to 24-week old ovariectomized $(O)$ or sham-operated (at 3 weeks)

female mice fed a control diet $(C)$ or a high fat diet $(L)$ ad libitum $(M \pm S E M)$

\begin{tabular}{|c|c|c|c|c|c|c|c|c|}
\hline & & c & & $\mathrm{CO}$ & & L & & LO \\
\hline \multirow{2}{*}{$\begin{array}{l}\text { Number of mice } \ldots \ldots \ldots \ldots \\
\text { Body weight }(\mathrm{g}) \ldots \ldots \ldots \ldots \\
\text { Food intake }(\mathrm{g} / 24 \mathrm{~h}) \ldots \ldots \ldots \\
\text { Food intake }(\mathrm{KJ} / 24 \mathrm{~h}) \ldots \ldots \\
\text { Food intake }(\mathrm{kJ} / 100 \mathrm{~g} \text { body } \\
\text { weight) } \ldots \ldots \ldots \ldots \ldots \ldots\end{array}$} & $\begin{array}{c}31.3 \\
5.33 \\
84.4\end{array}$ & $\begin{array}{l}13 \\
\pm 1.05 \\
\pm \pm 0.275 \\
\pm 0.96\end{array}$ & $\begin{array}{cc} & 34.7 \\
* & 4.55 \\
* & 73.6\end{array}$ & $\begin{array}{l}4 \\
\pm 1.14 \\
\pm 0.180 \\
\pm 1.50\end{array}$ & $\begin{array}{c}34.0 \\
4.01 \\
106.6\end{array}$ & $\begin{array}{l}11 \\
\pm 2.19 \\
\pm 0.133 \\
\pm 0.96\end{array}$ & $\begin{array}{cc}* \quad 42.6 \\
& 3.58 \\
& 92.8\end{array}$ & $\begin{array}{l}4 \\
\pm 2.82 \\
8 \pm 0.231 \\
\pm 2.59\end{array}$ \\
\hline & 237.8 & \pm 4.39 & $* * 176.0$ & \pm 1.50 & 231.6 & \pm 4.10 & $* * 162.6$ & \pm 2.26 \\
\hline
\end{tabular}

* Significant difference $p<0.05 ; * *$ Highly significant difference $p<0.01$.
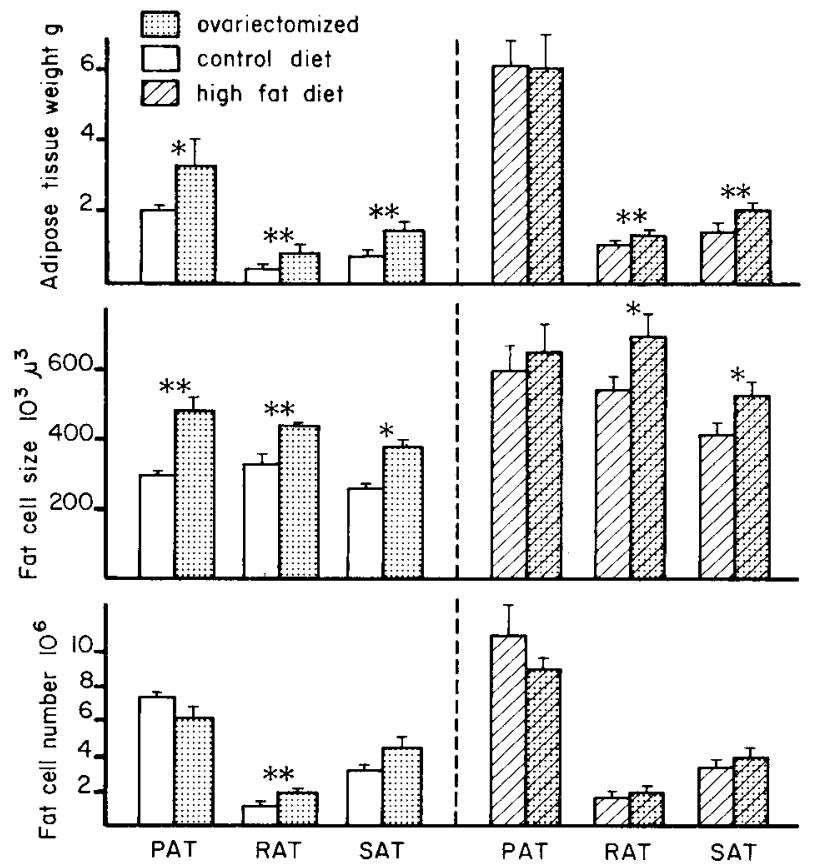

FIG. 1. - Adipose tissue cellularity of 32-week old female mice ovariectomized at 3 weeks and fed either a control diet or a high fat diet $(M \pm S E M) ; 6$ to 9 mice in each group. PAT : parametrial adipose tissue ; RAT : perirenal adipose tissue ; SAT : subcutaneous adipose tissue. * significant difference $\mathrm{P}<0.05, * *$ highly significant difference $\mathrm{P}<0.01$. 
Adipose tissue cellularity (fig. 1). - Ovariectomy in mice fed the control dief induced fat cell hypertrophy in the three fat depots : the size of the fat cells increased by 61 p. 100 in parametrial adipose tissue, by 34 p. 100 in the perirenal tissue and by 43 p. 100 in the abdominal subcutaneous fat pad. Only the perirenal adipose tissue showed hyperplasia ( +64 p. 100) in ovariectomized mice. Providing a high fat diet to the mice induced an increase in the fat cell size (parametrial : + 100 p. 100 ; perirenal : + 66 p. 100 ; subcutaneous adipose tissue : +63 p. 100) and also hyperplasia of the parametrial adipose tissue $(+48$ p. 100) and the perirenal fat pad (t 56 p. 100) $(P<0.01)$. Ovariectomy only affected fat cell size in the subcutaneous and perirenal adipose tissue and had no action on fat cell number when the mice ate a high fat diet.

\section{Discussion.}

Feeding a high fat dief to female mice induces obesity by increasing the fat cell size at the three sites and the cell number in the parametrial and perirenal regions (Lemonnier, 1972). This dietary obesity occurred with a moderate increase in caloric intake (table 2), the spontaneous exploratory activity remaining unchanged (Pallier ef al., 1979). The adipose cells from these obese mice showed high glucose utilization (mainly incorporation into glycerol-triglycerides), while the fatty acid moities were of dietary origin (Lemonnier et al., 1975).

In our study, withdrawal of gonadal steroids by ovariectomy resulted in increased body weight, which could not be related to a difference in growth, but to an augmentation of the adipose mass, as shown by the weight of the three fat pads. Kenney and Mook (1974) demonstrated that during 4 to 13 postoperative days, hyperphagia resulted in increased meal size and frequency. However, the hyperphagia induced by ovariectomy is temporary, for once an elevated body weight is attained, food intake drops to control levels (Blaustein and Wade, 1976). These authors demonstrated that during 30 to 50 postoperative days, while food intake returned to normal, meal patterns were still altered. When food intake was measured at 140 postoperative days in our experiment, it had decreased, suggesting that the heavier fat depots were unrelated to higher caloric intake.

Estrogens are thought to have weight-reducing effects (Wade and Zucker, 1970), but less is known about the concomitant changes in the composition and distribution of body fat. There is little evidence concerning the direct metabolic effects of sex hormones on the adipose tissue. Gilmour and Mc Kerns (1966) reported an increased glucose metabolism in isolated epididymal fat tissue in estrogen-treated animals. Owing to changes in other hormonal secretions, the indirect effects of estrogen action on adipose tissue must be taken into account. Estrogen administration is reported to elevate the insulin (Costrini and Kalkhoff, 1971) and growth hormone levels. These hormones increase the DNA content of adipose tissue, and insulin also induces fat cell enlargement, but they have not been shown to increase adipocyte number (Hollenberg and Vost, 1968 ; Vost and Hollenberg, 1970 ; Salans et al., 1972). Nevertheless, the final effect of administration may depend on the concurrent action of various antagonistic hormones. Krotkiewski (1976) observed that low estrogen doses injected in female rats induced fat cell size to increase only in the parametrial fat pad, which originally had the largest adipocytes. In contrast, high estrogen doses significantly 
decreased fat cell size in the subcutaneous tissue. This observation may be interpreted as regional specificity of the hormone effect on adipose tissue. Clinical experience shows that ovariectomy is often associated with increased body weight and, in some instances, with redistribution of the adipose tissue. In our experiment, withdrawing the ovarian hormones was followed by an increment of the adipose tissue. This gain in adipose mass weight in mice fed the control diet was due to fat cell hypertrophy at the three sites and to perirenal adipose fissue hyperplasia. Hyperplasia induced by the high fat diet was similar whether the animals were ovariectomized or not. Thus, the frequent hyperplasia observed in the parametrial adipose tissue of obese mice (Lemonnier and Alexiu, 1973) does appear to be related to the proximity of the ovaries. However, hyperplasia at that site has been induced by feeding a progesterone-enriched diet (Pallier ef al., 1979). Fat cell size in the obese ovariectomized mice only showed a further increase at the perirenal and subcutaneous adipose sites. Both ovariectomy and fat feeding increased fat cell number at the perirenal site. This must be related to the fact that the normal adult rat does not have a fixed fat cell number, and since adipocyte number at the perirenal site continuously increases normally, that process would likely be accelerated in fattening conditions (Lemonnier and Alexiu, 1973).

Our study suggests that changes in the hormonal status can modify fat cell number and/or size in different fat tissue regions. These regional differences are changed by diet.

Reçu en avril 1979.

Accepté en sepfembre 1979.

Acknowledgements. - This work was supported by an INSERM grant : Contrat de Recherche Libre No 75.4.024.7.

Résumé. Des souris femelles âgées de 3 semaines sont ovariectomisées. A partir du sevrage, à l'âge de 4 semaines, elles reçoivent ad libitum soit un régime témoin, soit un régime riche en lipides. A l'âge de 32 semaines les souris ovariectomisées sont plus grosses que leurs témoins opérés blanc, quel que soit le régime administré. Les ingesta mesurés à 140 jours après la castration sont diminués. L'ovariectomie, chez les souris recevant le régime témoin, induit une hypertrophie des cellules adipeuses dans les trois localisations et une hyperplasie des cellules dans le tissu adipeux périrénal. Chez les souris recevant un régime hyperlipidique, l'ovariectomie n'entraîne qu'une hypertrophie cellulaire supplémentaire dans le tissu adipeux sous-cutané et périrénal.

\section{References}

AUBERT R., SUQUET J.-P., LEMONNIER D., 1971. Effets à long terme de trois niveaux d'ingesta lactés sur les lipides corporels. C. R. Acad. Sci. Paris, Sér. D., 273, 2636-2638.

BATCHELOR B. R., MAHLER R. J., 1972. Growth hormone induced enhancement of insulin sensitivity in adipose tissue. Horm. Metab. Res., 4, 87-92.

BLAUSTEIN J. D., WADE G. N., 1976. Ovarian influences on the meal patterns of female rats. Physiol. Behav., 17, 201-208.

BROBECK J. R., WHEATLAND M., STROMINGER J. L., 1947. Variations in regulation of energy exchange associated $n$ ith estrus, diestrus and pseudopregnancy in rats. Endocrinology, 40, 65-72. 
COSTRINI N. V., KALKHOFF R. K., 1971. Relative effects of pregnancy, estradiol and progesterone on plasma insulin and pancreatic islet insulin secretion. J. clin. Invest., 50, 992-999.

GILMOUR K. E., MC KERNS K. W., 1966. Insulin and estrogen regulation of lipid synthesis in adipose tissue. Biochim. biophys. Acta, 116, 220-226.

HOLLENBERG C. N., VOST A., 1968. Regulation of DNA synthesis in fat cells and stromal elements from rat adipose tissue. J. clin. Invest., 47, 2485-2491.

KAKOLEWSKI J. W., COX V. C., VALENSTEIN E. S., 1968. Sex differences in body weight changes following gonadectomy of rats. Psychol. Rep., 22, 547-554.

KENNEY N. J., MOOK D. G., 1974. Effects of ovariectomy on meal pattern in the albino rat. J. comp. Physiol. Psychol., 87, 302-309.

KROTKIEWSKI M., 1976. The effects of estrogens on regional adipose tissue cellularity in the rat. Acta physiol. scand., 96, 128-133.

LEMONNIER D., 1972. Effect of age, sex, and site on the cellularity of the adipose tissue in mice and rats rendered obese by a high-fat diet. J. clin. Invest., 51, 2907-2915.

LEMONNIER D., ALEXIU A., 1973. Nutritional, genetic and hormonal aspects of adipose tissue cellularity. In VAGUE J., BOYER J. The regulation of the adipose tissue mass. Excerpta med. int. Congr. Ser., $n^{\circ} 315,158-173$.

LEMONNIER D., SUQUET J.-P., AUBERT R., DE GASQUET P., PEQUIGNOT E., 1975. Metabolism of the mouse made obese by a high-fat diet. Diab. Metabol., 1, 77-85.

PALLIER E., AUBERT R., LEMONNIER D., 1979. Effects of diel and progesterone on the cellularity of parametrial adipose tissue in mice. Ann. Biol. anim. Bioch. Biophys., 19, 1837-1842.

SALANS L. B., ZARNOWSKI M. J., SEGAL R., 1972. Effect of insulin upon cellular character,of rat adipose tissue. J. Lipid Res., 13, 616-623.

VOST A., HOLLENBERG C. H., 1970. Effects of diabetes and insulin on DNA synthesis in rat adipose tissue. Endocrinology, 87, 606-610.

WADE G. N., 1975. Some effects of ovarian hormones on food infake and body weight in female rats. J. comp. Physiol. Psychol., 88, 183-193.

WADE G. N., ZUCKER I., 1970. Modulation of food intake and locomotor activity in female rats by diencephalic hormone implants. J. comp. Physiol. Psychol., 72, 328-336. 